\title{
Abon Quality With The Main Substance Of Banana Blossom
}

\author{
Firlie Lanovia Amir ${ }^{1}$ and Ni Wayan Rena Mariani ${ }^{2}$ \\ Sekolah Tinggi Pariwisata Bali Internasional \\ Email: ${ }^{1}$ firlie@ @stpbi.ac.id and ${ }^{2}$ wynrena@stpbi.ac.id
}

\begin{abstract}
Abon is one type of food in form of meat fibers that being sliced and added by some spices, and then cooked until dry, abon usually consumed with rice or other kind of foods, usually used as bread stuffing. Banana tree is a fruit plant widely spread in southeast asia including Indonesia. Commonly, the only part of banana tree that being consumed is its fruit, and before the fruit is cooked usually banana heart first cut and discarded, many do not know that the heart of bananas or banana blossom contain good nutritional value and has many benefits, moreover it is good to be consumed by humans. Utilization and development of banana blossom in Indonesia has not been done optimally, because the selling value is still low and not balanced with the potential of the banana blossom. By looking at the production of banana blossom processing is still minimal, encouraging the author wants to utilize the heart of banana into the basic ingredient of making abon. The purpose of this study was to determine the quality of abon made from banana blossom seen in terms of taste, texture, aroma, and color. This research is quantitative, the data obtained from test instrument data, data collected and processed. The conclusion of this research is the quality of abon based on banana blossom that viewed in terms of taste (delicious) with got score 133, in terms of aroma (typical of abon) with 116 score, in terms of texture (quite crunchy) with 101 score and in terms of color (interesting) with 125 score. From the results of the assessment above, it can be concluded that the utilization of banana blossom in making abon get good category. So from this study, the heart of banana can be used in making abon.
\end{abstract}

Keywords_Efficiency, Banana Blossom, Abon

\section{INTRODUCTION}

Indonesia is a country with tropical climate. There are so many fruits that can grow in the tropics. Fruit is one type of food that contains nutrients, vitamins and minerals that are generally very good to be consumed every day. Fruits fuctions as regulator, both minerals and vitamins are needed by the human body to balance and enhance important sources for the body to facilitate digestion and to maintain health. Fruits that grow in the tropical area such as melon, orange, tomato, ambarella, papaya, apple, snakeskin and one of the most popular fruit is banana.

Banana blossom, or more accurately banana inflorescence is the ovary of the banana that will grow into the fruit. The use of this part of the plant is still very limited. In the efflorescence phase up to the shapping of fruit in the bunches, the remaining inflorescence will be cut off during the harvest and thrown away as it considered a waste even though the inflorescence itself contains a number of favorable nutrients such as protein, fat, carbohydrate, calcium, iron, phosphor, vitamin A, B and C.

Abon is a type of food that made of (commonly) meat fibers. It usually appears in light brownish or dark brown color due to the use of soy sauce. Abon looks like cotton fibers as it dominated with dried schredded muscle fibers. It can be storred for weeks or months in an airtight container because it contains very little amount of water. Other than meat (beef, lamb, pork, mutton) there are several Abon that made from fishes such as tuna, catfish, skipjack, even eel and shrimp.

Along with the times, Abon are widely varied with various materials. Banana inflorescence Abon is one kind that is not yet available even though it has a favorable nutritional value. Growth and massive use of banana tree as well as the fruits resulting in a lot of banana inflorescence waste as well. Considering the nutritional value of the inflorescence, it is important to try to make use of it and increase its economical value by using it as Abon ingredients. It attracts our attention and boost our interest to carry out a research to gain effective use of banana inflorescence as main ingredients of Abon 


\section{LITERATURE REVIEW}

Abon is a type of preserved food made of meat (beef, buffalo, fish) that shredded into the form of fibers or separated from it fibers then added with seasoning and fried. In Indonesian National Standard (SNI) 01-3707-1995 it is said that abon is a kind of dry food with distinct form, made of meat, boiled, slashed, seasoned, fried and pressed.

Abon is a preserved meat product that has been long known by the people. Data Central Statistic Body (BPS) (1993) in Sianturi (2000) points that Abon is fourth most produced goods. Abon is a ready to eat snacks or side dish. The product has been known by the people a long time ago. Abon is made from meat that is processed in such a way that has the characteristics of dry, crunchy and tasty. The meat that is generally used as Abon is either beef or buffalo (Suryani et al, 2007).

Banana inflorescence turns out can also be processed into Abon. As it considered as waste in the harvesting banana, causing many people unaware of the favorable nutrients contained in the inflorescence, that resulting in less economical value. There are so many favorable substances contained by the inflorescence that is needed by the human body. According to Industrial Research and Development Office (Balai Penelitian dan Pengembangan Industri) (1982) it is said that the inflorescence contain protein, fat, carbohydrate, calcium, iron, phosphor, as well as vitamin A, B and C. The content and nutritional composition of each type of banana is different.

\section{A. Banana Inflorescence Content}

TABLE I. NUTRITIONAL CONTENT (CHEMICAL COMPOSITION) OF BANANA INFLORESCENCE FROM SEVERAL TYPE OF BANANA (EVERY 100 GRAMS)

\begin{tabular}{llllllllll}
\hline $\begin{array}{l}\text { Type of } \\
\text { Banana }\end{array}$ & Protein & Fat & Carbohydrate & Calsium & Iron & Phospor & Vit & $\begin{array}{c}\text { Vit } \\
\text { A }\end{array}$ & Vit \\
& & & & & & & C \\
\hline Raja & 1,38 & 0,43 & 8,56 & 4 & 0,2 & 60 & 160 & 0,04 & 8 \\
Susu & 1,32 & 0,32 & 7,72 & 4 & 0,3 & 40 & 150 & 0,05 & 10 \\
Kapok & 1,26 & 0,35 & 8,31 & 6 & 0,4 & 50 & 140 & 0,06 & 9 \\
Klutuk & 2,10 & 0,46 & 6,24 & 8 & 0,7 & 60 & 170 & 0,03 & 7 \\
Lilin & 1,02 & 0,38 & 7,50 & 3 & 0,1 & 30 & 165 & 0,04 & 8 \\
\hline
\end{tabular}

Source: Industrial research and development office, East Java Surabaya (1982)

\section{B. The benefit of banana inflorescence as such:}

1. Prevent stroke: by using Ambon banana inflorescence. Boil the inflorescence, squeeze out the juice, drink twice a day to prevent stroke.

2. Preventing cholesterol build up: able to bind cholesterol to be excreted.

3. Nourish the stomach: the high fiber of the inflorescence helps the digestion system.

4. Food for diabetics: low glycemic index. Boiled inflorescence highly effective to lower the blood sugar rate.

5. High fiber: contain high dietary fiber such as carbohydrate, protein, mineral and vitamin (B1, Beta Carotene).

6. Good for diet: provide satisfaction of food in longer period rather than rice due to the fiber.

7. Facilitates blood cycle: banana inflorescence is an anticoagulant that prevents blood clotting.

8. Prevent Cancer: reducing free radicals effect. Free radicals may damage organ performance due to the oxidation that cause aging in cells. Methanol extract from banana inflorescence reacts as antioxidant to fight free radicals.

9. Anti Aging: the anti radical flavonoid may repair damaged cells.

10.Prevents Goiter: as it contains iodine.

11.Heals infections: it contains ethanol to prevent growth of bacteria.

12.Increase red blood cells production: it contains iron that also increases hemoglobin in the blood cells.

13.Control blood during menstruation: The boiled banana inflorescence, if consumed, may control the progesterone hormone that controls the release of menstrual blood.

14.Improve mood: contains magnesium that believed to helps with worries and improve mood 
15.Increase production of breast milk: as an alternative to sweet leaf (Katuk) that has been long known to increase breast milk production, banana inflorescence can also used as alternative food to increase breast milk production.

According to Suryani (2007) several additional seasoning that commonly used in the making of fish Abon is coconut milk, spices, sugar, salt and cooking oil.

1. Coconut milk is fat emulsion in water contained in coconut, colored white, squeezed from coconut flesh. Density of the coconut milk depends on the maturity of the coconut, and the amount of water used to extract the milk. The use of coconut milk will add flavors and nutritional value of a product. Coconut milk will add savory due to the high fat value the milk contained. Based on several researches, Abon that cooked with coconut milk will be more savory compared to abon that is cooked without coconut milk.

2. Spices (seasoning) that added in the production of abon intended to bring flavors and aroma that raise appetite. Types of spices used in the production of Abon are onion, garlic, candlenut, lemongrass and bay leaf. Other benefit in using spices is to preserve the Abon as spices may kill bacteria.

3. Sugar and salt. The use of sugar and salt in producing Abon is to enhance taste and improve texture of the Abon. In the production process, the sugar experience millard reaction that creates the brown color that makes the Abon more attractive and add sweet flavor. Salt $(\mathrm{NaCl})$ is an additional ingredient that almost always used in making a dish. The salty flavor of the salt acts as flavor enhancer. Salt can be used to preserve food as most of spoilage microbes; especially those with proteolytic character are very sensitive with salinity.

4. Cooking oil. The use of cooking oil in the abon production is as a heat conductor, savory enhancer, and to improve nutritional value especially calories contained in the foodstuffs.

\section{METHODS}

The experiment of the research are conducted in International Bali Institute of Tourism (STPBI), the institute was established with Decree of Minister of National Education, Republic of Indonesia number: 001/0/02008, is an institute of hotel and tourism studies that managed with professional management system and international standard quality. Our alumni is young professionals able to compete in local and international community, high creativity, high sense of entrepreneurship, with Indonesian character, virtuous and innovative in the field of hotel and tourism. The Bali Hotel School is a hotel school located in the heart of Denpasar with spacious campus area, comprehensive course facility, and quiet environment. The Bali Hotel School managed by Dharma Widya Ulangun Foundation with Establishment Deed Number 086 dated 27 March 2000 and course establishment permit number 13/055/W.21/LL.S/VIII/2000

Place $\quad:$ Kecak Kitchen Lab (with permit letter from Student Affairs Office)

Address : Jalan Tari Kecak No. 12 Gatot Subroto Timur Denpasar Bali

\section{A. Research Outcome and Discussion}

The research was conducted to increase the economic value of banana inflorescence that used as the main ingredients of Abon. The result observed is the the quality of the Abon from it taste, texture, color and aroma. The result of the experiment were then reviewed by 30 panelis to give score based on organoleptic (taste, texture, color, aroma) test. In the organoleptic test, 30 panelis are the expert of culinary consists of 3 instructors of culinary and 27 students of culinary $6^{\text {th }}$ semester of International Bali Institute of Tourism.

The following are the recap data in form of table and the data of the quality assessment. The instrument used is a closed questionnaire which is a method of collecting data by using detailed questions compeleted with list of answers. To test the quality using organoleptic test, likert scale was used to obtain score for taste, texture, color and aroma presented as follows. 
TABLE II DATA RECAP OF ORGANOLEPTIC TEST FOR ABON MADE FROM BANANA INFLORESCENCE

\begin{tabular}{lllllllll}
\hline No. Indicator & \multicolumn{9}{c}{ Score } & Total & Criteria \\
\cline { 3 - 7 } & & 5 & 4 & 3 & 2 & 1 & Score & \\
\hline 1 & Taste & 15 & 13 & 2 & 0 & 0 & 133 & Delicious \\
2 & Aroma & 5 & 16 & 9 & 0 & 0 & 116 & Abon Typical \\
3 & Texture & 3 & 7 & 18 & 2 & 0 & 101 & Fairly Crunchy \\
4 & Color & 8 & 19 & 3 & 0 & 0 & 125 & Attractive \\
\hline
\end{tabular}

Source: Questionnaire data from 30 panelists

TABLE III SCORE EXPLANATION

\begin{tabular}{|c|c|c|c|c|c|}
\hline \multirow[t]{2}{*}{ Atribute } & \multicolumn{5}{|c|}{ Score (Value) } \\
\hline & 5 & 4 & 3 & 2 & 1 \\
\hline Taste & Very Delicious & Delicious & $\begin{array}{l}\text { Fairly } \\
\text { Delicious }\end{array}$ & $\begin{array}{l}\text { Less } \\
\text { Delicious }\end{array}$ & Not Delicious \\
\hline Aroma & $\begin{array}{l}\text { Very Abon } \\
\text { Typical }\end{array}$ & Abon Typical & $\begin{array}{l}\text { Fairly Abon } \\
\text { Typical }\end{array}$ & $\begin{array}{l}\text { Less Abon } \\
\text { Typical }\end{array}$ & $\begin{array}{l}\text { Not Abon } \\
\text { Typical }\end{array}$ \\
\hline Texture & Very Crunchy & Crunchy & $\begin{array}{l}\text { Fairly } \\
\text { Crunchy }\end{array}$ & Less Crunchy & Not Crunchy \\
\hline Color & Very Attractive & Attractive & $\begin{array}{l}\text { Fairly } \\
\text { Attractive }\end{array}$ & $\begin{array}{l}\text { Less } \\
\text { Attractive }\end{array}$ & Not Attractive \\
\hline
\end{tabular}

Source: Pantiyasa, I Wayan (2017)

Based on table 4.1 it can be described that the organoleptic test of Abon with main ingredients of banana inflorescence scored by 30 panelists in the taste indicator the score is as follows: the panelists answers for very delicious (5) are 15 Panelists so the score is (5x15) 75, Panelists answers for Delicious (4) are 13 Panelist so the score is (4x13) 52, Panelists answers for Fairly Delicious (3) are so the score is (3x2) 6, No panelist answers for less delicious (2) so the score is 0 , No panelist answers for not delicious (1) so the score is 0 . Total score gained by Taste indicator is: $75+52+6=133$. So based on organoleptic test with the score of 133 it can be concluded that the taste is Delicious.

The result in the Aroma indicator is as follows: Panelist that answers very Abon Typical (5) are 5 Panelists so the score is (5x5) 25, Panelist that answers Abon Typical (4) are 16 Panelists so the score is $(4 \times 16)$ 64, Panelist that answers Fairly Abon Typical (3) are 9 Panelists so the score is (3x9) 27, No panelist answers for Less Abon Typical (2) so the score is 0, No panelist answers for Not Abon Typical (1) so the score is 0 . Total score gained by Aroma indicator is: $25+64+27=116$. So based on organoleptic test with the score of 116 it can be concluded that the aroma is Abon Typical.

The result in the Texture indicator is as follows: Panelist that answers very Crunchy (5) are 3 Panelists so the score is (5x3) 15, Panelist that answers Crunchy (4) are 7 Panelists so the score is (4x7) 28, Panelist that answers Fairly Crunchy (3) are 18 Panelists so the score is (3x18) 54, Panelist that answers Less Crunchy (2) are 2 Panelists so the score is (2x2) 4, No panelist answers for Not Crunchy (1) so the score is 0 . Total score gained by Texture indicator is: $15+28+54+4=101$. So based on organoleptic test with the score of 101 it can be concluded that the texture is Fairly Crunchy.

The result in the color indicator is as follows: Panelist that answers Very Attractive (5) are 8 Panelists so the score is (5x8) 40, Panelist that answers Attractive (4) are 19 Panelists so the score is (4x19) 76, Panelist that answers Fairly Attractive (3) are 3 Panelists so the score is (3x3) 9, No panelist answers for Less Attractive (2) so the score is 0, No panelist answers for Not Attractive (1) so the score is 0 . Total score gained by Texture indicator is: $40+76+9=125$. So based on organoleptic test with the score of 125 it can be concluded that the Color is Attractive. 


\section{B. Conclusion and Suggestion}

Based on the research outcome, it can be concluded from previous chapter that the quality of Abon made of Banana Inflorescence tasted (delicious) with the score of 133, with the aroma of (abon typical) with the score of 116, texture of (fairly crunchy) with the score of 101 and coloration (attractive) with the score of 125. From the result stated above it can be concluded that the use of banana inflorescence as main ingredients of abon gain a good mark. So in this research, the use of banana inflorescence in abon production can be used well.

From the research conducted and the outcome of the research, some suggestions may be given as follows:

1. The use of banana inflorescence as it good for human body and to increase its value need to be more varied. This kind of research is interesting and may provide more products to be commercialized.

2. The use of banana inflorescence as foodstuffs is very good due to the nutrition contained in it and hopefully this research can be developed further to produce abon of high quality that gain high price in the market.

\section{REFERENCE}

Anonim. 2013. Tanaman Obat-Herbal. (http;//tanamanobat-herbal.blogspot.co.id 2013/02/kandungan-dan-manfaat-jantung-pisang.html). Diakses pada tahun 2017.

Anonim. Manfaat pisang untuk pengobatan. 2010. dalam (http;//prana indonesia,wordpres.com/artikel/pisang-dan-manfaatnya/) diakses pada tahun 2017

Anonim. Riset dalam "the new englan journal of medicin". Dalam http://kekpisangvilla.com/info/10-khasiat-buah-pisang.html diakses pada tahun 2017

Pantiyasa, I Wayan. 2015. Pedoman Penulisan Tugas Akhir.Sekolah Tinggi Pariwisata Bali Internasional

Ririwa. 2009. All about food. (http;//ririwa.blogspot.co.id/2009/04/all-about- food.html?m=1) Diakses pada tahun 2009

Rukmana. 1999. Pengertian pisang pada umumnya. Dalam http;//eprints.uny.ac.id/9513/3/bab\%20\%2007308144038.pdf pada tahun 2017

Suyati dan Supriyadi, Ahmad. 2008. Pisang budi daya, Pengolahan dan Prospek Pasar

Penebar Swadaya : Jakarta hal 12, 14

Vison et al.2008. Menganalisis kuantitas dan kualitas buah pisang. Dalam http://lordbroken.wordpress.com/category/ilmu-dan-teknologi-pangan / pemanfaatan limbah / -diakses pada tahun 2017

Kusno, Gustaaf. 2016. Bahasa inggris jantung pisang. Dalam (http://m.kompasiana.com/gustaafkusno/apa-bahasa-inggrisnya-jantung- pisang). Diakses pada tahun 2017 